DOI 10.15290/cnisk.2018.01.05.05

DR HAB. ANETA DAWIDOWICZ

orcid.org/0000-0002-5266-2247

Uniwersytet Marii Curie-Skłodowskiej w Lublinie

\title{
The position of women in social life in the light of the National Party's political thought ${ }^{1}$
}

\begin{abstract}
In the interwar period, National Democracy (ND) journalists presented their own views regarding the postulates of the emerging feminist movement of that time. Women's position in social life was perceived in terms of the Catholic Church's teaching. ND journalists followed the existing stereotypes regarding femininity and masculinity patterns. They advocated the traditional role of women in the social domain. According to ND journalists, the rejection of this traditional model could have had a destructive impact on the entire national community. Therefore, women striving to get away from the traditional image, willing to devote themselves to a professional career at the cost of their family life, were perceived in a particularly negative way. In the public discourse on femininity, National Democracy took the conservative standpoint, which is also shared by representatives of modern national and nationalistic thought in Poland.
\end{abstract}

Keywords: women, political thought, National Party, interwar period, nationalism, social life, women's position

\footnotetext{
1 The publication was financed from the National Science Centre resources granted under Decision No. DEC-2013/09/B/HS5/00016. Tekst został opracowany w ramach projektu badawczego „Myśl polityczna Stronnictwa Narodowego (1928-1939)” finansowanego ze środków Narodowego Centrum Nauki na podstawie decyzji numer DEC-2013/09/B/ HS5/00016.
} 


\section{POZYCJA KOBIETY W ŻYCIU SPOEECZNYM W ŚWIETLE MYŚLI POLITYCZNEJ STRONNICTWA NARODOWEGO}

\section{Streszczenie}

W okresie międzywojennym publicyści Narodowej Demokracji zaprezentowali własne stanowisko wobec postulatów kształtującego się wówczas ruchu feministycznego. Pozycję kobiety w życiu społecznym pojmowano zgodnie $z$ wytycznymi Kościoła katolickiego. Publicyści endeccy akceptowali istniejace stereotypy określające wzorce kobiecości i męskości. Opowiadano się za tradycyjna rolą kobiety w życiu społecznym. Zdaniem publicystów endeckich odrzucenie tradycyjnego modelu mogło destrukcyjnie wpłynać na cała wspólnotę narodowa. Szczególnie negatywnie postrzegano kobiety, które odbiegały od tradycyjnego wizerunku i poświęcały się karierze zawodowej kosztem życia rodzinnego. W dyskursie publicznym dotyczącym kwestii kobiecej Narodowa Demokracja zajmowała stanowisko konserwatywne. Tożsame stanowisko zajmuja przedstawiciele współczesnej myśli narodowej i nacjonalistycznej w Polsce.

Słowa kluczowe: kobiety, myśl polityczna, Stronnictwo Narodowe, okres międzywojenny, nacjonalizm, życie społeczne, pozycja kobiet

\section{Introduction}

An increased interest in the social role of women, and their place in the social, economic and political life, was observed in the early 20th century. New phenomena, including the industrial revolution, along with the entry of women onto the labour market, and the progressing development of their professional activities, put the issues of women in a prominent place, and made them non-marginal to every political movement.

Two orientations were observed as regards the views concerning the social role of women. On the one hand, the traditionalist and behavioural orientation merely recognised women's place in the household and family domain, reducing their significance to maternal, care-taking and child-raising functions. The followers of this view considered women's professional activity as particularly dangerous, treating it as the source of all problems, the reason for family crises, and the collapse of the 
prevailing moral standards. It was stressed that the liberation of women from male dominance was against both the Catholic Church's teaching and human nature. It was also perceived as a material ethical threat, leading to moral decay and the weakening of the Polish nation ${ }^{2}$. On the other hand, progressive left-wing orientation was driven by (1) democratic, (2) liberal, (3) rationalistic, (4) secular, (5) anti-racist, (6) pacifistic, (7) pro-abortionist and (8) eugenic values ${ }^{3}$.

A change in women's standing was strongly influenced by the Great War, which, undoubtedly, had a much stronger impact on women's independence, and the adoption of new social roles, than the wars fought in previous centuries. These phenomena coincided with the accumulated effects of various movements, which had been launched much earlier, aiming at the legal and political equality of men and women. As a result, following World War I, the political and voting rights of women became a universally recognised demand which was met in most countries. While the fight for women's rights was only one of the manifestations of the prevailing tendency to revise the previous organisation of family life, the shift in women's position alone must have brought numerous changes to the life of every family ${ }^{4}$.

For a long time, the direction of changes in the family and everyday lives of European communities, including Polish, which prevailed in the interwar period, has been of much interest to representatives of numerous scientific fields. Between 1918 and 1939, the idea of women's

2 M. Śliwa, Wzorzec osobowy kobiety - socjalistki $w$ Polsce [A personal pattern of a socialist woman in Poland], [in:] Kobiety i edukacja na ziemiach polskich w XIX $i$ XX wieku [Women and education in the Polish land in the 19th and 20th centuries], Vol. 2, Part 1, ed. A. Żarnowska, A. Szwarc, Warsaw 1992, pp. 231-232.

3 See D. Kałwa, Głosy kobiet $w$ sprawie planowania rodziny $w$ świetle prasy $z$ lat 19291932 [Female voices regarding family planning in the light of press articles dated 19291932], [in:] Kobieta $i$ kultura życia codziennego wiek XIX $i$ XX [Women and the culture of everyday life in the 19th and 20th centuries], ed. A. Żarnowska, A. Szwarc, Warsaw 1997, pp. 123-132; M. Gawin, Planowanie rodziny - hasła i rzeczywistość [Family planning slogans $v$ s. reality], [in:] Równe prawa i nierówne szanse. Kobiety $w$ Polsce międzywojennej [Equal rights and unequal opportunities. Women in interwar Poland], ed. A. Żarnowska, A. Szwarc, Warsaw 2000, pp. 221-239; Eadem, Rasa i nowoczesność. Historia polskiego ruchu eugenicznego (1880-1952) [Race and modernity. The history of the Polish eugenics movement (1880-1952)], Warsaw 2003.

4 J. Żarnowski, Rodzina $w$ czasach cywilizacyjnego przyspieszenia: Europa i Polska 1918-1989 [The family in the times of civilisation acceleration: Europe and Poland 19181989], [in:] Rodzina - prywatność - intymność. Dzieje rodziny polskiej w kontekście europejskim [Family - privacy - intimacy. The history of the Polish family in the European context], ed. D. Kałwa, A. Walaszek, A. Żarnowska, Warsaw 2005, pp. 37-38. 
right to participate in social life to a broader extent, and in particular to participate in the public domain - from literature to politics - was spread in civilisationally and intellectually advanced social circles. Nonetheless, despite this trend, women pursuing political careers in the interwar period were very rare. The approval for women employed in executive positions, and for women doing more diverse jobs than the previously prevailing manual, care-taking and elementary teaching jobs, was also extremely slow ${ }^{5}$.

The progressive character of the Polish State in the times of the Second Republic of Poland, reflected in the granting of political rights to women, contrasted with the fierce battle they had to fight to improve their status in the matrimonial and family domain ${ }^{6}$. The postulates of the fight for equal rights, which were the subject-matter of public debate, along with changes to legal regulations, were markedly hard to realise in the domain of social awareness ${ }^{7}$.

\section{Axiological basis}

National Democracy, whose origins date back to the 1880s, had a permanent and strong influence on the development directions of the Second Republic of Poland. From the early days of independence, National Democracy, with its traditions of a political party active under the three partitions, managed to attract a large number of Polish people. In the interwar period, the ND party evolved from the Popular National Union (a parliamentary body), through the Camp of Great Poland, to the National Party. With time, and under the pressure exerted by the young generation, the National Party gradually returned to the Camp of Great Poland structure, and was subject to divisions ${ }^{8}$.

\footnotetext{
5 Ibidem, p. 40.

6 C. Kraft, Państwo wobec rodziny - polityka państw europejskich w XIX i XX wieku Polska na tle europejskim [The State and the family - the policies of European countries in the 19th and 20th centuries], [in:] Rodzina-prywatność - intymność..., p. 151.

7 See more: A. Nowak, M. Wójcik, Kobieta w rodzinie w II Rzeczypospolitej i współcześnie [A woman in a family in the Second Republic of Poland and now], Katowice 2000.

8 The status of research on the history and political thought of National Democracy is presented in: A. Dawidowicz, Dorobek historiografii ruchu narodowego w Polsce. Stan badan [The Polish national movement historiographical achievements. The status of research], [in:] Myśl polityczna w społeczenstwie informacyjnym [Political thought in the information society], scientific ed. E. Maj, E. Kirwiel, E. Podgajna, Lublin 2015, pp. 425-446.
} 
A uniform set of values, including the national community, respect for traditions and family, the Roman-Catholic religion, labour, private property, the sense of the hierarchy and the need for authority, and the craving for moral rebirth, became established in National Democracy circles. In ND political thought, the notion of nation was treated as a value exerting a decisive impact on other elements included in the set of professed values. The word national appeared to be overused by national ideologists, and all phenomena perceived by individuals were treated as national: (1) the system of preferred values was viewed as national, (2) political activities were of a national character and (3) social, economic and cultural activities were part of the national dimension ${ }^{9}$.

In the 1930s, such values as nation and fatherland were religiously sanctioned and formed part of the Christian philosophy of life, abandoning their original self-sufficiency manifested within the secular nationalist framework. The National Party (1928-1939) did not perceive the nation as the absolute, in the ideological sense. In line with the title of a publication by Jedrzej Giertych, the National Party represented the Christian (Catholic) nationalism type ${ }^{10}$. It clearly departed from the nationalism of the non-Christian type, thus disapproving of any attempts at representing the nation as the absolute. Treating the nation as the ultimate value was considered a pagan nationalist idea. J. Giertych claimed that

Perceiving the nation as the absolute good - as do the followers of some extreme nationalist directions - to which justice, law and morality must yield, and the service of which makes nothing sinful or criminal, represents a clearly pagan view ${ }^{11}$.

The journalist distinctly stated that the nation's good could not form the ultimate goal. According to Giertych, only God should be viewed as the ultimate good, whereas the nation's good, significant as it might seem, must yield to God's laws. Giertych did not doubt that nations were tem-

\footnotetext{
9 E. Maj, Pojęcie narodu i jego derywaty w publicystyce Zwiąku Ludowo-Narodowego [The notion of the nation and its derivatives in the Popular National Union's journalistic writing], [in:] Religia. Polityka. Naród. Studia nad wspótczesna myśla polityczna [Religion. Nation. Studies on contemporary political thought], ed. R. Łętocha, Kraków 2010, pp. 238-247.

10 J. Giertych, Nacjonalizm chrześcijański [Christian nationalism], Stuttgart 1948.

11 Ibidem, pp. 16, 34.
} 
poral entities: The nation's good, like individual family's well-being, must submit to moral law ${ }^{12}$.

\section{Social and moral issues}

Ideologists and journalists in National Democracy participated in the public debate on broadly-defined social problems. The issues related to morality and moral standards were frequently raised. They were inspired by the increased activity of women who demanded, at the outset of the 20th century, full economic independence, access to education, and fully equal rights vested in men and women. The development of feminist movement was an equally important factor contributing to such reflections.

With reference to moral issues, National Democracy ideologists voiced their support for the Catholic Church's standpoint. This dominated all their statements regarding the position of women and their role in social life. National Democrats, as the supporters of traditions and the conservative vision of social order, unconditionally accepted the social stereotypes, which had been handed down from generation to generation, regarding sex and the roles assigned to women. These stereotypes were usually based on physical and mental features, social roles, and predispositions to perform certain jobs ${ }^{13}$.

The traditional model of culture, according to which kindness, patience, submissiveness, protectiveness and empathy were attributed to women continued to prevail. The reference stereotypes and views formed the basis for the National Democracy's journalism to categorise and structure various social phenomena, eventually leading to self-identification ${ }^{14}$.

ND journalists viewed the traditionalistic model as optimal. On that basis, they negatively assessed any attempts to strive to get away from the traditional image. They claimed that, while being dedicated to professional career and achieving success, women did so at the cost

\footnotetext{
12 J. Giertych, Polski Obóz Narodowy [The Polish National Party], London 1977, p. 14.

13 G. Radomski, Feminizm jest nam obcy. Kwestia kobieca $w$ publicystyce Narodowej Demokracji w okresie międzywojennym [Feminism remains strange to us. Women's issues in the journalistic writing of the National Democracy in the interwar period], [in:] Narodowa Demokracja XIX-XXI wiek (Koncepcje - ludzie - działalność) [National Democracy in the 19th-20th centuries. (Concepts - people - activities)], ed. T. Sikorski, A. Wattor, Szczecin 2008, pp. 176-177.

14 Ibidem.
} 
of their family life. It was commonly believed that women should not "blindly" imitate men. Journalists often stressed that women had been naturally predetermined to perform the roles of mothers and care-givers, and they should not abandon their mission. Roman Dmowski, the unquestionable leader of National Democracy, was a zealous supporter of the traditional and ever-lasting division of roles. For his whole life, he remained faithful to the rigid and conservative views on morality, the family's social function and role division, which he had carried over from his own home. Dmowski grew up in a simple and traditional family, residing in the Targówek District in Warsaw. Brought up by rigid parents, he did not expect women to acquire education or display any interests going beyond their household or family, not to mention any inclination to take up any professional activity ${ }^{15}$. In her recollections, Maria Niklewiczowa neatly summarised Dmowski's views on so-called women's issues:

He held long discussions with Ela Balicka regarding the so-called emancipation of women, i.e. the woman's role in marriage, etc. Their views frequently differed and they sometimes argued, despite being close friends. 'Yes, Ela,'said Roman'I am as faithful to you [meaning women - A.D.] as a dog...

At this point, he would present a range of devastating arguments. To support his thesis that women should be mainly concerned about their homes, he would tell the following story. One day he got invited to dinner by his friend, whose wife was engaged in social work. He turned up on time but the housewife was not in. She came back late, as a result of which the dinner was also delayed. When the husband asked what she was planning to serve for dinner, she responded Ask the cook. She's seeing to that. Obviously, as Roman later said, the dinner was tasteless, and the beefsteak was too stiff; that's how it ends when a woman gets fed up with being a woman ${ }^{16}$. At this point, we might refer to Dmowski's

15 J. Niklewska, Roman Dmowski $i$ kobiety $w$ świetle jego korespondencji z lat 1915-1920 [Roman Dmowski and women in the light of his correspondence dated 1915-1920], [in:] Archiwum Narodowej Demokracji [The National Democracy archive], Vol. 1, ed. J. Engelgard, M. Motas, Warsaw 2013, pp. 67-92.

${ }_{16}$ M. Niklewiczowa, Pan Roman. Wspomnienia o Romanie Dmowskim [Sir Roman. Recollections of Roman Dmowski], Warsaw 2001, p. 21. 
famous saying which clearly reflects his opinion on the issue of women. There are women who know nothing, and witches who know everything ${ }^{17}$.

Nonetheless, national work performed by women was sporadically accepted in National Democracy circles. It is worth noting that, despite supporting the traditional social model, some ND followers encouraged women to take up different forms of activities, not only in the educational domain, with some of the Party members being women. Therefore, it was not odd that the longest female MP career in the interwar period was pursued by Gabriela Balicka (an MP representing the Popular National Union, the National Party) between 1919 and $1935^{18}$. Gabriela was married to a renowned ND activist and ideologist, Zygmunt Balicki. Other MPs representing National Democracy included Zofia Sokolnicka, Władysława Ładzina, Ewelina Pepłowska and Maria Holder-Eggerowa. All of them belonged to the National Women's Organisation ${ }^{19}$.

\section{Women's role in social life}

In the first half of the 20th century, an ideologically-motivated growth in the State's interest in family issues was observed across Europe. More attention was being paid to family life, with a shift in the State's interest from the economic domain to the family's reproductive functions. This revaluation was reflected in the growing significance of eugenic discourses. Such issues as pregnancy, childbirth and maternity, which had been previously treated as belonging to the private domain, and, hence, non-political, became the fully-fledged subject-matter of political discourse ${ }^{20}$. In the interwar period, family and childbirth planning

\footnotetext{
17 Ibidem; K. Kawalec, Roman Dmowski 1864-1939, Wrocław-Warsaw-Kraków 2002, p. 86. 18 Gabriela Balicka (1871-1962) - studied natural sciences in Geneva, earning the Ph.D. degree in this field. From 1893 she was active in the National League. She managed the seminar of the Society for the Protection of Women, intended for female teachers. She was also active in the National Organisation for Women and a member of the Popular National Union's authorities. Between 1922 and 1927 she was a Member of Parliament.

19 E. Maj, Zwiazek Ludowo-Narodowy 1919-1939. Studium z dziejów myśli narodowej [The Popular National Union 1919-1939. A study of the history of national thought], Lublin 2000, p. 69; P. Gołdyn, Maria Holder-Eggerowa i jej zaangażowanie w ratowanie kobiet zagrożonych prostytucja [Maria Holder-Eggerowa and her attempts at saving women threatened with prostitution], [in:] Roman Dmowski i jego wspólpracownicy [Roman Dmowski and his collaborators], ed. M. Białokur, M. Patelski, A. Szczepanik, Toruń 2008, pp. 278-288. 20 C. Kraft, op. cit., p. 153; D. Kałwa, op. cit. See also: I. Krzywicka, Kontrola wspótczesności. Wybór międzywojennej publicystyki społecznej i literackiej z lat 1924-1939
} 
was increasingly discussed in social journalism. The use of contraceptives fostered, to some extent, the emergence of a family model with a limited number of children. Such practices were vigorously fought down by the Catholic Church, with Poland being a country where it had a strong impact on both law-making and social practice ${ }^{21}$.

Texts on the phenomenon of social injustice can scarcely be found in the political journalistic writing of National Democracy. While there were no postulates to launch a social reform of moral standards, the ideas disseminated by representatives of the so-called Polish progressive intelligence with democratic and liberal views were violently opposed. Such issues as: 1) birth control, 2) the promotion of sexual awareness among young people, 3) abortion, 4) female sexuality problems or 5) homosexualism obviously met with strong disapproval. National journalists rejected the significance of the ongoing moral transitions. The introduction of partner relations and intimate issues to public discourse was considered unnecessary and even despicable ${ }^{22}$.

In the political thought of the Polish nationalism, women were considered the symbolic care-takers of the nation who embodied collective life, and whose task was to reproduce the national culture. Political journalists of National Democracy invariably stressed that women were naturally inclined to function as mothers and care-takers. It was believed that their sense of fulfilment was only possible through childbirth. Any attempts at avoiding maternity were assessed negatively and viewed as potentially leading to family breakdown and social demoralisation, ultimately threatening the whole national community.

Efforts to liberate women from their maternal duties were treated by national ideologists as tightly connected with Judeo-Communist influence. The vision of matrimonial law, as appearing in journalistic writing, was consistent with the Catholic Church's teaching. Family re-

[Contemporariness under control. A selection of interwar social and literary articles dated 1924-1939], gathered and supplemented with introductory remarks by A. Zawiszewska, Warsaw 2008.

${ }^{21}$ J. Żarnowski, op. cit., p. 40.

22 See A. Nowaczyński, Ofensywa. Donna Krzywicka [The Offensive. Donna Krzywicka, "The devilis disciple”], „Myśl Narodowa” [National Thought] 1932, No. 31, pp. 458-459; idem, Ofensywa. Safona z Y.P.S.U. [The Offensive. Safona from Y.P.S.U.], „Myśl Narodowa" [National Thought] 1933, No. 27, p. 399. See also: J. Babiński, Obiady czwartkowe. Kompleks p. Krzywickiej [Thursday dinners. Ms Krzywicka's complex] „Merkuriusz Polski Ordynaryjny" [The Polish Mercury Ordinary] 1934, No. 8, pp. 18-19. 
lations were expected to be based on male dominance. As regards the attitude to professional activities pursued by women, it was believed that they could lead to demoralisation. In numerous journalistic texts, women were presented as excellent housewives. While their professional activities were rarely accepted, there was much approval for their scientific careers.

Generally speaking, according to national ideologists, women should act as the strongest link in religious and national education. The education of future generations, and thus the future of the entire Polish nation, was viewed as dependent on their moral attitude and attachment to both religious and national values. It was commonly believed in the national ideologist circles that the patriarchal family model could act as the source of moral and religious rebirth. Engagement in rosary prayer groups and occupational associations of a religious character was, therefore, seen as the desirable form of women's activity. In order to make women aware of their social role, the ideal female role models from the past were disseminated, including Saint Jadwiga of Poland and Izabella Czartoryska.

This mental return to the ideas prevailing in the Middle Ages meant that the national ideologists drew their inspiration from the political thought of mediaeval authorities, including Saint Augustine and Saint Thomas Aquinas ${ }^{23}$. The ideological influence of Saint Augustine became evident in the concept of family as promoted by the National Party in the 1930s. The National Party ideologists perceived families as the basis of the entire national life, and also as an invariably important foundation of the nation's existence. This institution was treated as indispensable for human and social development. An ideal family should display strong emotional bonds and a structure relating to the Old-Testament patriarchalism. According to ideologists and journalists, family bonds shaped the attitudes of unselfishness and altruism ${ }^{24}$. While raising the family issue, approval was expressed for traditional moral values ${ }^{25}$. The traditionalist family model with a hierarchical internal structure was, according to the National Party's political thought, compliant with nature and God's laws.

\footnotetext{
${ }^{23}$ J. Mosdorf, W młodzieży nadzieja Polski [Poland's hope lies in the youth], „Myśl Narodowa" [National Thought] 1933, No. 15, pp. 193-194; A. Doboszyński, O odsetkach [About interest], „Myśl Narodowa” [National Thought] 1933, No. 29, pp. 415-417.

24 Z. Raczkowski, Ludzie bezdomni [The homeless], „Myśl Narodowa” [National Thought] 1931, No. 26, pp. 338-340.

25 R. Rybarski, O państwie policyjnym [About a surveillance state], „Myśl Narodowa” [National Thought] 1933, No. 20, pp. 273-275.
} 
Women were assigned an extremely prominent place in that model. They were mainly expected to protect the national, and traditionally Polish, values and to hand them on to future generations. While discussing family issues, the national ideologists promoted the inseparability of marriage and the idea of having many children, while condemning bachelorhood and families with one child or no children ${ }^{26}$. The family was believed to convey the ideal patterns, behavioural standards and values, and to provide protection against destructive behaviour, detrimental to the development and interests of both individuals and the nation as a whole. The National Party declared the need to ensure legal protection for families and married couples ${ }^{27}$. Care for the development of Polish families was one of the most persistent and regularly raised issues in the national press, with harmonious and unbreakable family life being seen as a real value ${ }^{28}$.

In discussions of family issues in the press, an aversion to women's emancipation attitudes and efforts was clearly manifested ${ }^{29}$. Feminist slogans and theories were viewed as foreign, destructive and inconsistent with the actual social needs. The idea that the role of mother and care-taker was inherent to women, leading to their ultimate self-fulfilment, was widely disseminated. In consequence, various initiatives inspiring women to take up salaried work were much to the National Party's dislike ${ }^{30}$. As stressed in Myśl Narodowa [National Thought], one of the leading opinion-making periodicals,

education should prepare women to perform the roles which are naturally assigned to them. The spiritual structure, interests and desires displayed by women must not be independent of their biological

\footnotetext{
26 J. Giertych, Po wyborach w Eodzi. Obserwacje i wnioski [The Eódź election. Observations and conclusions], Warsaw 1936, p. 30; R. Rybarski, op. cit., p. 274.

27 The Scientific Library of the Polish Academy of Sciences and the Polish Academy of Learning in Kraków, Józef Zieliński's files, Materials regarding the history of the National Party. The organisation and propaganda between 1928 and 1939, Statutes, regulations, instructions and papers. A political pamphlet. The 4th National League stands for election to fight for the landlord's right of the Polish Nation in their own country, mf. 1448, sg. 7820, without page numbers (hereinafter: b.p.).

${ }_{28}$ K.S. Frycz, Na widowni [In the audience], „Myśl Narodowa” [National Thought] 1936, No. 48, p. 757; Tydzien propagandy trzeźwości [The sobriety propaganda week], „Głos Lubelski" [The Lublin Voice] 1930, No. 19, p. 5.

29 A. Świętochowski, Liberum veto, „Myśl Narodowa” [National Thought] 1929, No. 8, pp. 121-122.

30 J. Rembieliński, Emancypacja od... feminizmu [Emancipation from... feminism], „Myśl Narodowa" [National Thought] 1933, No. 29, p. 422.
} 
functions of mothers and care-takers. (...) Women are different from men, not only in the physical, but also in the spiritual, sense. They are neither superior nor inferior, but simply different. As such, one cannot speak of women equalling men but rather of the former acquiring the abilities to properly manifest their distinct uniqueness, not only in the instinctive but also the mental plane ${ }^{31}$.

Taking into consideration the common good of the national community, the negative consequences for the development of the Polish nation were sought in destructive notions and phenomena which, according to nationalist journalists, had been brought to Poland by Jews, Communists and Masons. Hedonism, materialism, consumptionism, internationalist and cosmopolite ideas, atheism and feminism were listed among the false ideas and "pseudo-values" which could threaten the national community. The above-mentioned ideas were also viewed as detrimental to families, as promoting false models and erroneous perceptions of women's position and rights in the social domain. Following the same logic, protectionism, snobbism, incompetence, "the cult of money" and "the drive for living above means" were stigmatised. Given the critical attitude towards the ideological heritage of the French Revolution, the preferred system of values made no room for equality. Questioning the significance of equality, a journalist of Myśl Narodowa pondered,

Where has this new equality religion come from? It cannot be found in the Ancient Greek or Roman worlds, nor was it present in the Middle Ages or in the ancien régime Europe. It was not advocated by Plato or Aristotle, or presented in Roman Jurists' works, or discussed by Saint Thomas Aquinas ${ }^{32}$.

The diagnoses and analyses of the existing status quo were accompanied by a "new man" education postulate, with a pious, submissive and modest man, primarily focused on national, spiritual and "lofty" values, being seen as the ideal ${ }^{33}$. At the same time, fears were expressed that the

\footnotetext{
31 A.A., Wychowanie narodowe. Sprawa wyksztatcenia kobiet [National education. The issue of women's education], „Myśl Narodowa” [National Thought] 1929, No. 17, p. 267.

32 Viator, Mistyka demokratyczna [Democratic mystisque], „Myśl Narodowa” [National Thought] 1929, No. 18, p. 275.

33 R. Dmowski, Ludzie potrzebni [The needed people], „Myśl Narodowa” [National Thought] 1933, No. 54, p. 813; J. Giertych, O wyjście $z$ kryzysu... [About emerging from the crisis], p. 201; W. Wasiutyński, Najmłodsze pokolenie przez pryzmat „Myśli nowoczesnego
} 
secularisation of attitudes, coupled with the disappearance of traditional standards and values, would push the Polish nation towards a moral and spiritual crisis. Concerns were spread that "the triumph of materialistic thought, the collapse of traditionalism" and the development of democratic institutions would pave the way for the destructive activities launched by Jews, Communists and Masons ${ }^{34}$.

Considerations regarding women's role in social life were closely connected with the issues of national education. Women were thought to play a prominent and exceptional role in the national education process. The National Democrats were convinced that it was the family where the extremely important inter-generation transition of national values took place. Family values were enthusiastically advocated by Roman Dmows$\mathrm{ki}$, who wrote that the family is a link between the individual and society, and society is mainly formed by families, not individuals ${ }^{35}$. According to National Democracy supporters, it was the family which laid the foundation for the nation's existence, being indispensable to human and social development. The ideal family should display strong emotional bonds and a structure relating to Old-Testament patriarchalism. According to ideologists and journalists, family bonds shaped the attitudes of unselfishness and altruism ${ }^{36}$. While raising the family issue, approval was expressed for traditional moral values ${ }^{37}$. The traditionalist family model with a hierarchical internal structure was, according to the National Party's political thought, compliant with natural and God's laws. Women were assigned an extremely important place in that model, as they were were expected to protect the national and traditionally Polish values and to hand them on to future generations ${ }^{38}$. While discussing family issues, the national ideologists promoted the inseparability of marriage and the

Polaka" [The youngest generation seen through the prism of the modern Pole's thought], „Myśl Narodowa” [National Thought] 1931, No. 40, p. 112; Z. Wasilewski, Na widowni [In the audience], „Myśl Narodowa” [National Thought] 1937, No 36, p. 568.

34 K.S. Frycz, Pozytywizm [Positivism], „Myśl Narodowa” [National Thought] 1934, No. 41, pp. 594-596.

${ }_{35}$ R. Dmowski, Pisma, t. X...[Letters, vol. X...], p. 218.

36 Z. Raczkowski, op. cit., pp. 338-340.

37 R. Rybarski, op. cit., pp. 273-275.

38 How the "Mother-Pole" patterns have changed in the Polish culture, see E. Kępa, Patriotyzm kobiet - ewolucja i przeobrażenia Matki Polki w kulturze współczesnej [Women's patriotism - the evolution and transitions of the Mother-Pole in the contemporary culture], [in:] Patriotyzm a wychowanie [Patriotism vs. education], ed. E.J. Kryńska, J. Dąbrowska, A. Szarkowska, U. Wróblewska, Białystok 2009, pp. 556-566. 
idea of having many children, while condemning bachelorhood and families with one child or no children ${ }^{39}$. The family was believed to hand on the correct patterns, behavioural standards and values, and to provide protection against destructive behaviour, detrimental to the development and interests of both individuals and the nation as a whole. The National Party declared the need to ensure legally guaranteed family and marriage protection ${ }^{40}$. Care for the development of Polish families was one of the persistent and regularly raised issues in the national press, with harmonious and unbreakable family life being seen as a real value ${ }^{41}$.

When discussing family issues, aversion to women's emancipation attitudes and attempts was clearly manifested in the press ${ }^{42}$. Feminist slogans and theories were viewed as foreign, destructive and inconsistent with the actual social needs. The idea that the role of a mother and caretaker was inherent to women, and thus the most socially useful, was widely disseminated. An opinion expressed by one of the journalists, Jan Rembieliński, appears rather symptomatic. He claimed that a woman can display more individuality and creativity when sewing a dress for her child than when working in the office and typing letters or circulars dictated by her superior ${ }^{43}$. In consequence, various initiatives inspiring women to take up salaried work were much to the National Party's dislike ${ }^{44}$. As stressed in „Myśl Narodowa” [National Thought]:

\footnotetext{
39 J. Giertych, Po wyborach $w$ Łodzi..., op. cit., p. 30; R. Rybarski, op. cit., p. 274.

40 The Scientific Library of the Polish Academy of Sciences and the Polish Academy of Learning in Kraków, Józef Zieliński's files, materials regarding the history of the National Party. The organisation and propaganda between 1928 and 1939, statutes, regulations, instructions and papers. A political pamphlet. The 4th National League stands for election to fight for the landlord's right of the Polish Nation in their own country, mf. 1448, sg. 7820, without page numbers (hereinafter: b.p.).

${ }^{41}$ K.S. Frycz, Na widowni [In the audience], „Myśl Narodowa” [National Thought] 1936, No. 48, p. 757; Tydzien propagandy trzeźwości [The sobriety propaganda week], „Głos Lubelski" [The Lublin Voice] 1930, No. 19, p. 5. In the political thought of the contemporary national and nationalist groupings, the family constitutes the principal value. The key role of family in the process of the education of the young generation is still strongly accentuated. See more: E. Maj, Myśl narodowa i nacjonalistyczna [National and nationalist thought], [in:] Myśl polityczna $w$ Polsce po 1989 roku. Wybrane nurty ideowe [Political thought in Poland after 1989. Selected ideological trends], ed. E. Maj, A. Wójcik, Lublin 2008, pp. 116126; G. Radomski, Rewitalizacja koncepcji edukacyjnych Narodowej Demokracji w koncepcjach wspótczesnego ruchu narodowego w Polsce [Revitalisation of the National Democracy educational concepts in the concepts of the contemporary national movement in Poland], [in:] Epigoństwo czy twórcza ciagłość?... [Epigonism or creative continuance?...], pp. 185-187.

42 A. Świętochowski, op. cit., pp. 121-122.

43 J. Rembieliński, op. cit., p. 422.

44 Ibidem.
} 
education should prepare women to perform the roles which are naturally assigned to them. The spiritual structure, interests and desires displayed by women must not be independent of their biological functions of mothers and care-takers. (...) Women are different from men, not only in the physical but also spiritual sense. They are neither superior nor inferior, but simply different. As such, one cannot speak of women equalling men but rather of the former acquiring the abilities to properly manifest their distinct uniqueness, not only in the instinctive but also mental plane ${ }^{45}$.

The idea of national education was to build a strong nation, and to prepare society for an independent national and State life. The condition of the Polish society was thoroughly analysed. An active and constructive attitude was inspired, along with promoting social responsibility, engagement, willingness to make sacrifices, self-denial, and submission to the will of entities responsible for the accomplishment of set objectives. National education was expected to lead to establishing "the definitive Polish type" reflecting the Polish identity and traditional values cultivated from generation to generation by the native Polish population. Such a type could only be possible through imposing the right discipline and hierarchy.

\section{Final remarks}

In the interwar period, National Democracy journalists presented their own views regarding the emerging feminist movement. The National Democracy invariably held a conservative position in the public discourse on women's issues. Its representatives were faithful to the conservative and traditional view that women should mainly perform the role of wives, mothers and housewives. Despite the traditional respect, or even reverence for the female population, women's participation in public life met with disapproval. Women found it hard to pave their way to public presence in society and to exercise their rights in various domains to the same extent as men did.

The position of women in the social domain was perceived in line with the Catholic Church's teaching. ND journalists followed the existing

\footnotetext{
45 A.A., Wychowanie narodowe. Sprawa wyksztakcenia kobiet [National education. The issue of women' education], „Myśl Narodowa” [National Thought] 1929, No. 17, p. 267.
} 
stereotypes regarding femininity and masculinity patterns. They were in favour of the traditional role of women in the social domain. According to ND journalists, the rejection of this traditional model could have had a destructive impact on the entire national community. Therefore, women striving to get away from the traditional image, willing to devote themselves to a professional career at the cost of their family life, were perceived in a particularly negative way. It should be added that these views are also shared by representatives of modern national and nationalistic thought in Poland.

\section{Bibliography}

\section{Archive materials}

The Scientific Library of the Polish Academy of Sciences and the Polish Academy of Learning in Kraków, Józef Zieliński's files, materials dealing with the history of the National Party. The organisation and propaganda between 1928 and 1939, statutes, regulations, instructions and papers. A political pamphlet. 4 „Lista Narodowa staje do wyborów aby wywalczyć Narodowi Polskiemu prawo gospodarza we własnym państwie" [The National List stands for election to fight for the right of the Polish Nation to be hosts in their own country], mf. 1448, ref. 7820.

\section{Political texts and journalistic writing}

A.A., Wychowanie narodowe. Sprawa wykształcenia kobiet [National education. The issue of women's education], „Myśl Narodowa” [National Thought] 1929, No. 17, p. 267.

Babiński Julian, Obiady czwartkowe. Kompleks p. Krzywickiej [Thursday dinners. Ms Krzywicka's complex], „Merkuriusz Polski Ordynaryjny” [The Polish Mercury Ordinary] 1934, No. 8, pp. 18-19.

Dmowski Roman, Ludzie potrzebni [The needed people], „Myśl Narodowa” [National Thought] 1933, No. 54, p. 813.

Doboszyński Adam, O odsetkach [About interest], „Myśl Narodowa” [National Thought] 1933, No. 29, pp. 415-417.

Frycz Karol Stefan, Na widowni [In the audience], „Myśl Narodowa” [National Thought] 1936, No. 48, p. 757. 
Frycz Karol Stefan, Pozytywizm [Positivism], „Myśl Narodowa” [National Thought] 1934, No. 41, pp. 594-596.

Giertych Jędrzej, Nacjonalizm chrześcijański [Christian nationalism], Stuttgart 1948.

Giertych Jędrzej, Po wyborach $w$ Łodzi. Obserwacje $i$ wnioski [The Łódź election. Observations and conclusions], Warsaw 1936.

Giertych Jędrzej, Polski Obóz Narodowy [The Polish National Party], London 1977.

Mosdorf Jan, W młodzieży nadzieja Polski [Poland's hope lies in the youth], „Myśl Narodowa” [National Thought] 1933, No. 15, pp. 193-194.

Nowaczyński Adolf, Ofensywa. Donna Krzywicka [The Offensive. Donna Krzywicka], „Myśl Narodowa” [National Thought] 1932, No. 31, pp. 458-459.

Nowaczyński Adolf, Ofensywa. Safona z Y.P.S.U. [The Offensive. Safona from Y.P.S.U.], „Myśl Narodowa” [National Thought] 1933, No. 27, p. 399.

Raczkowski Zygmunt, Ludzie bezdomni [The homeless], „Myśl Narodowa” [National Thought] 1931, No. 26, pp. 338-340.

Rembieliński Jan, Emancypacja od... feminizmu [Emancipation from... feminism], „Myś1 Narodowa” [National Thought] 1933, No. 29, p. 422.

Rybarski Roman, O państwie policyjnym [About the surveillance State], „Myś1 Narodowa" [National Thought] 1933, No. 20, pp. 273-275.

Świętochowski Aleksander, Liberum veto, „Myśl Narodowa” [National Thought] 1929, No. 8, pp. 121-122.

Tydzień propagandy trzeźwości [Sobriety propaganda week], „Głos Lubelski” [The Lublin Voice] 1930, No. 19, p. 5.

Viator, Mistyka demokratyczna [Democratic mystique], „Myśl Narodowa” [National Thought] 1929, No. 18, p. 275.

Wasilewski Z., Na widowni [In the audience], „Myśl Narodowa” [National Thought] 1937, No. 36, p. 568.

Wasiutyński Wojciech, Najmłodsze pokolenie przez pryzmat "Myśli nowoczesnego Polaka" [The youngest generation seen through the prism of the modern Pole's thought], „Myśl Narodowa” [National Thought] 1931, No. 40 , p. 112. 


\section{Recollections}

Niklewiczowa Maria, Pan Roman. Wspomnienia o Romanie Dmowskim [Sir Roman. Recollections of Roman Dmowski], Warsaw : Znak, 2001, ISBN: 978-83-880-6756-3.

\section{Scientific papers}

Dawidowicz Aneta, Dorobek historiografii ruchu narodowego w Polsce. Stan badan' [The Polish national movement's historiography achievements. The status of research], [in:] Myśl polityczna w spoleczeństwie informacyjnym [Political thought in the information society], scientific ed. Ewa Maj, Eleonora Kirwiel, Ewelina Podgajna, Lublin : Wydawnictwo UMCS, 2015, pp. 425-446.

Gawin Magdalena, Planowanie rodziny - hasła i rzeczywistość [Family planning - slogans vs. reality], [in:] Równe prawa i nierówne szanse. Kobiety $w$ Polsce międzywojennej [Equal rights and unequal opportunities. Women in interwar Poland], ed. Anna Żarnowska, Andrzej Szwarc, Warsaw : Wydawnictwo DiG, 2000, pp. 221-239.

Gawin Magdalena, Rasa i nowoczesność. Historia polskiego ruchu eugenicznego (1880-1952) [Race and modernity. The history of the Polish eugenics movement (1880-1952)], Warsaw : Neriton, 2003, ISBN 83-88973-57-6.

Gołdyn Piotr, Maria Holder-Eggerowa i jej zaangażowanie $w$ ratowanie kobiet zagrożonych prostytucja [Maria Holder-Eggerowa and her attempts at saving women threatened with prostitution], [in:] Roman Dmowski i jego wspótpracownicy [Roman Dmowski and his collaborators], ed. Marek Białokur, Mariusz Patelski, Andrzej Szczepanik, Torun : Wydawnictwo Adam Marszałek, 2008, pp. 278-288.

Kałwa Dobrochna, Głosy kobiet w sprawie planowania rodziny w świetle prasy z lat 1929-1932 [Female voices regarding family planning in the light of press articles dated 1929-1932], [in:] Kobieta i kultura życia codziennego wiek XIX iXX [Women and the culture of everyday life in the 19th and 20th centuries], ed. Anna Żarnowska, Andrzej Szwarc, Warsaw : Wydawnictwo DiG, 1997, pp. 123-132.

Kawalec Krzysztof, Roman Dmowski 1864-1939. Wrocław-Warsaw-Kraków : Zakład Narodowy im. Ossolińskich, 2002, ISBN 83-04-04565-6. 
Kępa Ewa, Patriotyzm kobiet - ewolucja i przeobrażenia Matki Polki w kulturze współczesnej [Women's patriotism - evolution and transitions of the Mother-Pole in the contemporary culture], [in:] Patriotyzm a wychowanie [Patriotism vs. education], ed. Elwira Jolanta Kryńska, Joanna Dabrowska, Agnieszka Szarkowska, Urszula Wróblewska, Białystok : Trans Humana, 2009, pp. 556-566.

Kraft Claudia, Państwo wobec rodziny - polityka państw europejskich $w$ XIX i XX wieku - Polska na tle europejskim [The State towards the family the policies of European countries in the 19th and 20th centuries], [in:] Rodzina - prywatność - intymność. Dzieje rodziny polskiej w kontekście europejskim [Family - privacy - intimacy. The history of the Polish family in the European context], ed. Dobrochna Kałwa, Adam Walaszek, Anna Żarnowska, Warsaw : Instytut Historii PAN, Instytut Historyczny UW, 2005, pp. 105-121.

Krzywicka Irena, Kontrola współczesności. Wybór międzywojennej publicystyki spolecznej i literackiej z lat 1924-1939 [Contemporariness under control. A selection of interwar social and literary articles dated 1924-1939], gathered and supplemented with introductory remarks by Agata Zawiszewska, Warsaw : Fundacja Feminoteka, 2008, ISBN: 9788362206643.

Maj Ewa, Myśl narodowa i nacjonalistyczna [National and nationalist thought], [in:] Myśl polityczna w Polsce po 1989 roku. Wybrane nurty ideowe [Political thought in Poland after 1989. Selected ideological trends], ed. Ewa Maj, Alicja Wójcik, Lublin : Wydawnictwo UMCS, 2008, pp. 116-126.

Maj Ewa, Pojęcie narodu i jego derywaty w publicystyce Zwiazku Ludowo-Narodowego [The notion of the nation and its derivative in Popular National Union's journalistic writing], [in:] Religia. Polityka. Naród. Studia nad wspótczesna myśla polityczna [Religion. Nation. Studies on thecontemporary political thought], ed. Rafał Łętocha, Kraków : NOMOS, 2010, pp. 238-247.

Maj Ewa, Zwiazek Ludowo-Narodowy 1919-1939. Studium z dziejów myśli narodowej [The Popular National Union 1919-1939. A study of the history of national thought], Lublin : Wydawnictwo UMCS, 2000, ISBN: 83-2271585-4.

Niklewska Jolanta, Roman Dmowski i kobiety $w$ świetle jego korespondencji $z$ lat 1915-1920 [Roman Dmowski and women in the light of his correspondence dated 1915-1920], [in:] Archiwum Narodowej Demokracji [The 
National Democracy archive], Vol. 1, ed. Jan Engelgard, Maciej Motas, Warsaw : Wydawnictwo Myśl Polska, 2013, pp. 67-92.

Nowak Anna, Wójcik Mirosław, Kobieta $w$ rodzinie $w$ II Rzeczypospolitej $i$ wspótcześnie [A woman in a family in the Second Republic of Poland and now], Katowice : Wydawnictwo Uniwersytetu Ślaskiego, 2000, ISBN 8322609159.

Radomski Grzegorz, Feminizm jest nam obcy. Kwestia kobieca w publicystyce Narodowej Demokracji w okresie międzywojennym [Feminism remains strange to us. Women's issues in the journalistic writing of the National Democracy in the interwar period], [in:] Narodowa Demokracja XIX-XXI wiek (Koncepcje - ludzie - działalność) [The National Democracy in the 19th-20th centuries (Concepts - people-activities)], ed. Tomasz Sikorski, Adam Wator, Szczecin : Wydział Humanistyczny Uniwersytetu Szczecińskiego, 2008, pp. 176-177.

Śliwa Michał, Wzorzec osobowy kobiety - socjalistki w Polsce [A personal pattern of a socialist woman in Poland], [in:] Kobiety i edukacja na ziemiach polskich w XIX iXX wieku [Women and education in the Polish land in the 19th and 20th centuries], Vol. 2, Part 1, ed. Anna Żarnowska, Andrzej Szwarc, Warsaw : Instytut Historyczny Uniwersytetu Warszawskiego, 1992, pp. 231-232.

Żarnowski Janusz, Rodzina w czasach cywilizacyjnego przyspieszenia: Europa i Polska 1918-1989 [Family in the times of civilisation acceleration: Europe and Poland 1918-1989], [in:] Rodzina - prywatność - intymność. Dzieje rodziny polskiej $w$ kontekście europejskim [Family - privacy - intimacy. The history of the Polish family in the European context], ed. Dobrochna Kałwa, Adam Walaszek, Anna Żarnowska, Warsaw : Wydawnictwo DiG, 2005, pp. 37-58. 